\title{
Comparative Analysis of Chromium and Cadmium in Various Parts of Wheat and Maize
}

\author{
Namrah Awan', Ammara Fatima ${ }^{2 *}$, Muhammad Farhan' \\ ${ }^{1}$ Sustainable Development Study Center, Government College University, Lahore \\ ${ }^{2}$ Department of Environmental Sciences, Lahore College for Women Universty, Lahore
}

Received: 15 November 2017

Accepted: 20 January 2018

\begin{abstract}
The rise in the human population is a major factor contributing toward increased environmental contamination. Rampant industrialization and urbanization has resulted in the discharge of hazardous materials in the environment, making it unfit for life. Inorganic pollutants accumulate themselves in edible or non-edible parts of the cultivated crops and as a result they become part of the food chain. Concentrations of chromium and cadmium were measured in various parts of edible crops, i.e., wheat and maize. Random sampling was done in the field irrigated with sewage water and fresh water in the vicinity of Okara. It was a comparative study between crops irrigated with fresh and waste waters. After profound analysis, it was found that the level of cadmium increased by 4.81-fold in stems, 1.87-fold in leaves, 1.23 -fold in grains, and 2.96-fold in roots of the wheat samples that were being treated with sewage water compared to that of freshwater samples, respectively, and the concentration of cadmium increased by 2.14 -fold in roots, 8.29-fold in leaves, and 6.84-fold in stems of the maize samples, respectively. A similar trend was observed in concentrations of chromium. Results were also compared to the standards suggested by FAO/WHO, but the amount of cadmium and chromium in both freshwater and wastewater irrigated samples were higher compared to the standards. Therefore, wastewater irrigation must be controlled in order to ensure human health safety.
\end{abstract}

Keywords: heavy metals, sewage water, crop irrigation, bioaccumulation

\section{Introduction}

An upsurge of the human population has contributed majorly toward environmental contamination. The rapid increase in industrial as well as economic development all around the world has resulted in the discharge of toxic emissions that are unsuitable for soil, water, and, ultimately, crop yields. Therefore, this increased

*e-mail: Ammara_sajid@yahoo.com toxicity has triggered apprehensions related to food safety [1].

The rising demand of food security has invigorated research concerning hazards concomitant with the ingestion of foods adulterated by pesticides and inorganic pollutants. Food safety issues and plausible health hazards both contribute to make one of the most severe environmental concerns [2]. Heavy metals are categorized as potential environmental pollutants having the ability to cause serious health hazards in the case of their presence in excessive amounts. Heavy metals can cause noxious effects even at very minor concentrations 
and therefore are given unusual consideration all around the world [3].

Various anthropogenic activities including industrialization, agricultural production, mining, and transport contribute toward the release of noxious heavy metals, which ultimately become part of the environment [4]. Inorganic pollutants like heavy metals easily get accumulated in plants that are transferred in humans through the ingestion of contaminated food. Heavy metals may enter the human body through the ingestion of contaminated food grown in polluted soil and by drinking polluted water [2].

Heavy metals are also non-biodegradable, which means that they bio accumulate themselves in the food chain rather than being degraded. They have a persistent behavior in nature and their bioavailability adversely affects soil as well as crops [5]. Chances of heavy metal accumulation increase greatly in food items that are cultivated in contaminated soil as compared to those grown in uncontaminated soil [6]. Contamination of foodstuff with heavy metals is one of the most important aspects of food quality assurance [7].

A number of hazardous chemicals and varying amounts of contaminants can be found in wastewater, which depends entirely on its source and level of treatment. General problems that may occur from the use of domestic sewage for irrigational purposes include excessive concentrations of inorganic pollutants, nutrients, salts, noxious organic compounds, and organic matter [8]. Various studies conducted in this context show that irrigating with treated and untreated wastewater has the potential to change properties of soil [9].

The higher accumulation rates of toxic metals in crops irrigated with wastewater has already been witnessed by several researchers, and it is enough to cause disorders in plants and medical problems in both humans as well as animals that consume these plants [10]. Many agrarians use industrial wastewater and sewage water for irrigational purposes in Pakistan due to the lack of fresh irrigational water in the country. According to one report, almost $80 \%$ of the residents use sewage or unprocessed wastewater for irrigation in Pakistan [11].

Cadmium is an extremely toxic and dangerous metal even at a minor concentration because it does not take any part in the human biological system but rather accumulates at toxic levels [12]. Various negative impacts of $\mathrm{Cd}$ metals have also been reported in plants related to its health and growth mechanism [13]. Anemia, kidney damage, lung cancer, and bone disorders are general outcomes resulting from $\mathrm{Cd}$ poisoning in humans [14].

Chromium is a vital element necessary for the breakdown of fats and normal sugar levels and is therefore effective in managing diabetes. Generally, some compounds of chromium are not considered to be hazardous, but $\mathrm{Cr}(\mathrm{VI})$ has some cancer-causing properties [15].
Various investigators have already studied heavy metal accumulation in soil [16, 17], drinking water [16], and food items [16-18]; simultaneously, the effects of sewage water effluent on health have also been widely studied $[16,19,20]$. A significant aim of our study was to find the difference between heavy metals (cadmium and chromium) accumulation in edible crops irrigated with fresh water and sewage water. In order to achieve this aim, some complementary objectives were also designed, which include the quantification of cadmium and chromium levels in wheat as well as maize crops. Another objective was to measure the order of metal buildup rate in various parts of crops for which roots, leaves, stems, and seeds were analyzed separately.

\section{Materials and Methods}

\section{Work Plan}

Our present research was a comparative study to evaluate the concentrations of chromium and cadmium in various parts of edible crops, specifically wheat and maize. The Okara Region was opted as the sampling area mainly because it is an agricultural city in Punjab, Pakistan. Random sampling was done for collection of samples. The main focus of the study conducted from March to June 2015 in the Environmental Science Department of Lahore College for Women University (LCWU), Lahore.

\section{Sampling Plan}

Standard sampling techniques were followed in order to ensure the integrity of results. Two different sites were selected for random sampling in Okara: one for collecting freshwater samples and the other for sewage water samples. Plastic bags were used to place crop samples, and analysis was performed in LCWU. Proper labeling of sampling bags was done to specify the site from which each sample was collected.

\section{Pre-Treatment of Samples}

During the first step of the process, fresh samples of wheat and maize were thoroughly washed with water. Washed and clean samples were dried by placing them on a filter paper sheet for 12 hours. The sheet absorbed the excess amount of water in samples. Roots, leaves, stems, and seeds of the sample were separated in order to analyze metal uptake for every part of the edible crop separately. After separation, parts of crops were further cut into small pieces and placed in an oven for 72 hours at $70^{\circ} \mathrm{C}$ in petri dishes. Samples were oven-dried to remove all moisture content. After drying, samples were ground to coarse powder with the help of a grinder. Samples were sieved after grinding using a $1 \mathrm{~mm}$ mesh sieve [21]. These 
Table 1. Comparison of heavy metal accumulation $(\mathrm{mg} / \mathrm{kg})$ in various parts of wheat and maize under fresh water and sewage water irrigation.

\begin{tabular}{|c|c|c|c|c|c|c|c|}
\hline \multirow[b]{2}{*}{ Species } & \multirow[b]{2}{*}{ Part of plant } & \multicolumn{2}{|c|}{ Conc. of cadmium $(\mathrm{mg} / \mathrm{kg})$} & \multirow{2}{*}{$\begin{array}{c}\text { WHO } \\
\text { Standard for Cd } \\
(\mathrm{mg} / \mathrm{kg})\end{array}$} & \multicolumn{2}{|c|}{ Conc. of chromium $(\mathrm{mg} / \mathrm{kg})$} & \multirow{2}{*}{$\begin{array}{c}\text { WHO Standard } \\
\text { for } \mathrm{Cr} \\
(\mathrm{mg} / \mathrm{kg})\end{array}$} \\
\hline & & $\begin{array}{c}\text { Freshwater } \\
\text { irrigation }\end{array}$ & $\begin{array}{c}\text { Sewage water } \\
\text { irrigation }\end{array}$ & & $\begin{array}{c}\text { Freshwater } \\
\text { irrigation }\end{array}$ & $\begin{array}{c}\text { Sewage water } \\
\text { irrigation }\end{array}$ & \\
\hline \multirow{4}{*}{ Wheat } & Stem & $0.1633 \pm 0.02$ & $0.7867 \pm 0.01$ & 0.1 & $9.039 \pm 0.39$ & $13.33 \pm 0.26$ & 1 \\
\hline & Leaves & $0.3217 \pm 0.01$ & $0.6043 \pm 0.01$ & 0.1 & $10.33 \pm 0.27$ & $14.08 \pm 0.33$ & 1 \\
\hline & Grains & $0.9317 \pm 0.04$ & $1.153 \pm 0.02$ & 0.1 & $11.473 \pm 0.34$ & $12.67 \pm 0.38$ & 1 \\
\hline & Roots & $0.673 \pm 0.02$ & $1.997 \pm 0.03$ & 0.1 & $11.41 \pm 0.41$ & $21.68 \pm 0.69$ & 1 \\
\hline \multirow{3}{*}{ Maize } & Stem & $0.4783 \pm 0.01$ & $3.272 \pm 0.21$ & 0.1 & $10.712 \pm 0.47$ & $16.79 \pm 0.69$ & 1 \\
\hline & Leaves & $0.7747 \pm 0.01$ & $6.424 \pm 0.32$ & 0.1 & $9.803 \pm 0.41$ & $14.917 \pm 0.43$ & 1 \\
\hline & Roots & $0.2233 \pm 0.01$ & $0.4777 \pm 0.02$ & 0.1 & $8.699 \pm 0.39$ & $13.067 \pm 0.47$ & 1 \\
\hline
\end{tabular}

dried and ground samples were stored in airtight polythene bags to prevent moisture, heat, light, and insect damage.

\section{Wet Digestion}

$0.5 \mathrm{~g}$ of prepared samples of each part of crops (leaves, stems, roots, and seeds) were taken in a glass flask. Approximately $5 \mathrm{ml}$ of concentrated $\mathrm{HNO}_{3}$ was mixed with weighed samples to make solution. The same procedure was repeated in an empty flask in order to make a blank sample [22]. An electric hot plate (HP 220, UTEC Products Inc., Albany N.Y., USA) was used to heat samples for about an hour at $75-85^{\circ} \mathrm{C}$. Temperature was further raised above $120^{\circ} \mathrm{C}$, and samples were allowed to boil at this high level. 3-5 $\mathrm{ml}$ of concentrated $\mathrm{HNO}_{3}$ and $30 \% \mathrm{H}_{2} \mathrm{O}_{2}$ were occasionally added into the flask to continue the digestion process. The addition of chemicals continued until a pure solution was obtained. Filter paper (Whatman No. 42) was used to filter the solution after cooling and was diluted up to $20 \mathrm{ml}$ with distilled water. After filtration, the solution was stored in clean and airtight bottles for further analysis. The concentrations of cadmium and chromium in wheat and maize samples were determined with the help of atomic absorption spectrophotometry (AAS).

\section{Results and Discussion}

Pakistan is an agricultural country and its economy depends largely on this sector. Wheat and maize are among the major cash crops of Pakistan. Unfortunately, water shortages and scarcity are forcing farmers to use industrial effluents and sewage water as a cheaper substitute for fresh irrigation water. Although wastewater is a useful source of nutrients for soil, it also contains excessive amounts of heavy metals and other harmful pollutants. These metals in soil accumulate in edible or non-edible parts of the cultivated crops and as a result they become part of the food chain. Concentrations of chromium and cadmium in various parts of edible crops (i.e., wheat and maize) were determined in our current study. Major emphasis of the present study was to evaluate the difference between metal accumulation rate in the crops treated with fresh water and sewage water.

\section{Concentrations of Cadmium in Wheat}

The concentration of cadmium was detected in four different parts of wheat (roots, grains, leaves, and stems) irrigated with fresh water. The order of $\mathrm{Cd}$ accumulation in wheat detected after analysis was grains $(0.9317 \mathrm{mg} / \mathrm{kg})>\operatorname{roots}(0.673 \mathrm{mg} / \mathrm{kg})>$ leaves $(0.3217 \mathrm{mg} / \mathrm{kg})>$ stems $(0.1633 \mathrm{mg} / \mathrm{kg})$. The same method of study was also applied on wheat crops treated with sewage water. The order of $\mathrm{Cd}$ accumulation in wheat of sewage water was roots $(1.997 \mathrm{mg} / \mathrm{kg})>$ grains $(1.153 \mathrm{mg} / \mathrm{kg})>$ stems $(0.7867 \mathrm{mg} / \mathrm{kg})>$ leaves $(0.6043 \mathrm{mg} / \mathrm{kg})$ (Table 1). A similar case study conducted on wheat crops suggested that wheat cultivated in soil polluted with cadmium has a greater chance of causing health issues to human and is not suitable for planting [23]. On the whole, concentrations of cadmium were elevated in wastewater-irrigated wheat samples as

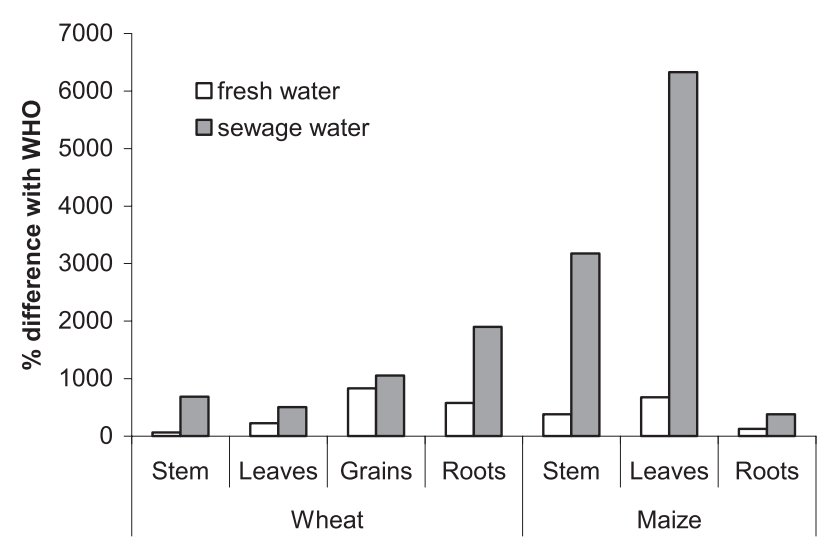

Fig. 1. Comparing Cd concentrations in wheat and maize samples with standards. 
compared to the samples that were being treated with fresh irrigational water. The level of cadmium increased by 4.81 -fold in stems, 1.87-fold in leaves, 1.23-fold in grains, and 2.96-fold in roots of the wheat samples irrigated with wastewater as compared to the freshwater samples (Fig. 1). A conclusion was drawn from similar research that although wastewater plays an important role in improving soil fertility, it must be used with caution as it has adverse effects on the quality of crops and soil functions [24].

\section{Concentrations of Cadmium in Maize}

Concentrations of $\mathrm{Cd}$ were also found in three different parts of maize crops in the same manner. The order of $\mathrm{Cd}$ accumulation in maize treated with fresh water found in the present study was leaves $(0.7747 \mathrm{mg} / \mathrm{kg})>$ stems $(0.4783 \mathrm{mg} / \mathrm{kg})>$ roots $(0.2233 \mathrm{mg} / \mathrm{kg})$. The order of $\mathrm{Cd}$ accumulation detected after analysis in maize treated with sewage water was leaves $(6.424 \mathrm{mg} / \mathrm{kg})>$ stems $(3.272 \mathrm{mg} / \mathrm{kg})>$ roots $(0.4777 \mathrm{mg} / \mathrm{kg})$ (Table 1$)$. The reason for the high concentration of cadmium in domestic sewage and wastewater could be its excessive use in $\mathrm{Cd} / \mathrm{Ni}$ batteries, as pigment, stabilizers, cleaners, stimulants, and in electronic compounds [25]. Contradictory research conducted in northwestern China showed that accumulation rates of cadmium in maize are lower compared to wheat, and that it can be planted in cadmium-polluted oasis soil [23]. On the whole, concentrations of cadmium were elevated in wastewater-irrigated maize samples as compared to the samples being treated with fresh irrigational water. The level of cadmium increased by 2.14 -fold in roots, 8.29-fold in leaves, and 6.84-fold in stems of the maize samples irrigated with wastewater as compared to freshwater samples (Fig. 1). A number of similar or related studies have already been completed and their findings are somehow parallel to the present study. An analogous study in Pakistan determined the influence of domestic sewage on metal accumulation in canola. Leaf area, quantity of leaves, and yield rate were all affected by sewage water application. Negative effects were seen on growth and yield of plants [26].

\section{Concentrations of Chromium in Wheat}

Using the same methodology, concentrations of chromium were also detected in wheat. Four different parts of wheat (roots, grains, leaves, and stems) treated with fresh water were studied. The order of $\mathrm{Cr}$ accumulation in wheat found in the present study was grains $(11.473 \mathrm{mg} / \mathrm{kg})>\operatorname{roots}(11.41 \mathrm{mg} / \mathrm{kg})>$ leaves $(10.33 \mathrm{mg} / \mathrm{kg})>$ stems $(9.039 \mathrm{mg} / \mathrm{kg})$. The same method of study was applied to wheat crops treated with sewage water. The amount of chromium detected after analysis was $21.68 \mathrm{mg} / \mathrm{kg}$ for roots, $12.67 \mathrm{mg} / \mathrm{kg}$ for grains, $14.08 \mathrm{mg} / \mathrm{kg}$ for leaves, and $13.33 \mathrm{mg} / \mathrm{kg}$ for stems of wheat. The order of $\mathrm{Cr}$ accumulation in wheat with sewage water treatment was roots $(21.68 \mathrm{mg} / \mathrm{kg})$ $>$ leaves $(14.08 \mathrm{mg} / \mathrm{kg})>$ stems $(13.33 \mathrm{mg} / \mathrm{kg})>$ seeds $(12.67 \mathrm{mg} / \mathrm{kg})$ (Table 1). On the whole, concentrations of chromium were elevated in wastewater-irrigated wheat samples as compared to the samples being treated with fresh irrigational water. The level of chromium increased by 1.47 -fold in stems, 1.36 -fold in leaves, 1.1-fold in grains, and 1.9-fold in roots of the wheat samples irrigated with wastewater as compared to the freshwater samples (Fig. 2). Somewhat parallel results were obtained in research conducted to investigate risks related to wastewater reuse for irrigational purposes. A moderate risk was detected due to the presence of chloride [27].

\section{Concentrations of Chromium in Maize}

Concentrations of $\mathrm{Cr}$ were also found in maize crops. The order of $\mathrm{Cr}$ accumulation in maize irrigated with fresh water was stem $(10.712 \mathrm{mg} / \mathrm{kg})>$ leaves $(9.803 \mathrm{mg} / \mathrm{kg})>$ roots $(8.699 \mathrm{mg} / \mathrm{kg})$. The amount of cadmium detected after analysis was $13.067 \mathrm{mg} / \mathrm{kg}$ for roots, $14.917 \mathrm{mg} / \mathrm{kg}$ for leaves, and $16.79 \mathrm{mg} / \mathrm{kg}$ for stems of maize. The order of $\mathrm{Cr}$ accumulation in wheat treated with sewage water was stems $(16.79 \mathrm{mg} / \mathrm{kg})>$ leaves $(14.917 \mathrm{mg} / \mathrm{kg})>$ roots $(13.067 \mathrm{mg} / \mathrm{kg}$ ) (Table 1). On the whole, concentrations of chromium were elevated in wastewater-irrigated maize samples as compared to the samples being treated with fresh irrigational water. The level of chromium increased by 1.5 -fold in roots, 1.52 -fold in leaves, and 1.57 -fold in stems of the maize samples irrigated with wastewater as compared to the freshwater samples (Fig. 2). Mining and manufacturing processes are also considered to be a threat due to the resulting contamination of soil. Research was designed to investigate soil contamination in a gold-mining area. Results showed that metals within soil were under permissible limits but inhabitants were at risk of healthrelated problems [28].

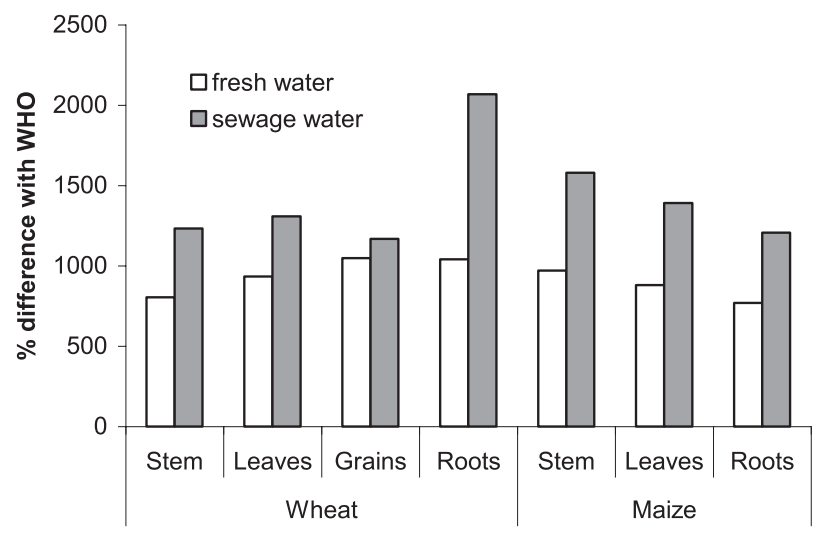

Fig. 2. Comparison of $\mathrm{Cr}$ concentrations in wheat and maize samples with standard. 


\section{Comparison with WHO}

A huge percentage difference with standards was observed in all samples. Comparatively, samples treated with sewage water were found to have elevated rates of metal accumulation. The highest percentage difference of cadmium concentration with standards was found in wheat roots and in leaves of maize plants treated with sewage water. For chromium metal, the highest difference was found in wheat roots and in stems of maize plants. The same trend was reported in the latest research conducted on Berseem (fodder type), where the highest cadmium content was found in roots while the highest chromium content was reported in leaves of the crop $[29,30]$.

\section{Conclusion}

Contamination of edible crops with heavy metals and other inorganic pollutants can cause a number of detrimental effects to human beings. A major source of cadmium in domestic sewage is its use in $\mathrm{Ni} / \mathrm{Cd}$ batteries, as dyestuff, stabilizers for PVC, detergents, fertilizers, and electrical compounds, whereas chromium is released from electroplating processes, leaching from soil into groundwater, and disposal of chromiumcontaining waste. The current study was piloted to find the concentrations of cadmium and chromium in wheat and maize crops. It was a comparative study between crops treated with fresh and waste irrigational water. After analysis, we concluded that concentrations of cadmium and chromium were elevated in wastewaterirrigated samples as compared to the samples being treated with fresh irrigational water. Results were also compared to the standards suggested by FAO/WHO, but the amount of heavy metals $(\mathrm{Cd}$ and $\mathrm{Cr})$ in both freshwater- and wastewater-irrigated samples were higher as compared to the standards.

\section{Acknowledgements}

The authors are thankful to the Department of Environmental Sciences at the Lahore College for Women University for providing necessary facilities to conduct this research.

\section{Conflict of Interest}

The authors declare no conflict of interest.

\section{References}

1. YANG Y., ZHANG F.S., LI H.F., JIANG R.F. Accumulation of cadmium in the edible parts of six vegetable species grown in Cd-contaminated soils. J. Environ. Manage. 90, 1117, 2009.
2. GEBREGZIABHER B., TESFAYE S. Assessment of leaves of lead, cadmium, copper and zinc contamination in selected edible vegetables. Int. J. Innov. Appl. Stud. 7(1), 78, 2014.

3. HAWARE D.J., PRAMOD H.P. Determination of specific heavy metals in fruit juices using atomic absorption spectroscopy (AAS). Int. J. Res. Chem. Environ. 4 (3), 163, 2014.

4. SHARMA S., KAUR I., NAGPAL A.K. Assessment of arsenic content in soil, rice grains and groundwater and associated health risks in human population from Ropar wetland, India, and its vicinity. Environ. Sci. Pollut. Res. 24, 18836, 2017.

5. CHOONG Y.Y., NORLI I., ABDULLAH A.Z., YHAYA M.F. Impacts of trace element supplementation on the performance of anaerobic digestion process: a critical review. Bioresour. Technol. 209, 369, 2016.

6. BEMPAH C.K., KWOFIE A.B., TUTU A.O., DENUTSUI D., BENTIL N. Assessing potential dietary intake of heavy metals in some selected fruits and vegetables from Ghanaian markets. Elixir Pollut. 39, 4921, 2011.

7. AKLILU A., MENGISTU S., FISSEHA I. Determining the extent of contamination of vegetables affected by tannery effluent in Ejersa area of East Shoa, Ethiopia. Int. J. Sci. Res. Publ. 3 (5), 1, 2013.

8. QADIR M., MATEO-SAGASTA J., JIMÉNEZ B., SIEBE C., SIEMENS J. HANJRA M.A. Environmental risks and cost-effective risk management in wastewater use systems. Wastewater: Economic Asset in an Urbanizing World, Springer. 2015.

9. ABEGUNRIN T.P., AWE G.O., IDOWU D.O., ONIGBOGI O.O., ONOFUA O.E. Effect of wastewater irrigation on soil properties and growth of cucumber (Cucumis sativa). J. Soil Sci. Environ. Manag. 4 (7), 139, 2013.

10. KASHIF S.R., AKRAM M., YASEEN M., ALI S. Studies on heavy metal status and their uptake in adjoining areas of Hudiara drain in Lahore. Soil. Environ. 28 (1), 7, 2009.

11. KHALIL S., KAKAR M.K. Agricultural use of untreated wastewater in Pakistan. Asian J. Agric. Rural Develop. 1, 21, 2011.

12. AMBEDKAR G., MUNIYAN M. Analysis of heavy metals in water, sediments and selected fresh water fish collected from Gadilam River, Tamilnadu, India. Int. J. Toxicol. Appl. Pharmacol. 2 (2), 25, 2012.

13. TRAN T.A., POPOVA L.P. Functions and toxicity of cadmium in plants: recent advances and future prospects. Turkish Journal of Botany. 37, 1, 2013.

14. EDWARD J.B., IDOWU E.O., OSO J.A., IBIDAPO O.R. Determination of heavy metal concentration in fish samples, sediment and water from Odo-Ayo River in AdoEkiti, Ekiti-State, Nigeria. Int. J. Environ. Monit. Anal. 1 (1), 27, 2013.

15. KALAGBOR I.A., BARISERE V., BARIVULE G., BARILE S., BASSEY C. Investigation of the presence of some heavy metals in four edible vegetables from a cottage farm in Port Harcourt. Res. J. Environ. Earth Sci. 6 (1), 18, 2014.

16. CHEN L., ZHOU S., SHI Y., WANG C., LI B., LI Y., WU S. Heavy metals in food crops, soil, and water in the Lihe River Watershed of the Taihu Region and their potential health risks when ingested. Science of the Total Environment. 615, 141, 2018.

17. URBANO V.R., MENDONCA T.G., BASTOS R.G., SOUZA C.F. Effects of treated wastewater irrigation on soil properties and lettuce yield. Agricultural Water Management. 181, 108, 2017. 
18. FUSI A., GONZALEZ-GARCÍA S., MOREIRA M.T., FIALA M., BACENETTI J. Rice fertilised with urban sewage sludge and possible mitigation strategies: an environmental assessment. Journal of Cleaner Production. 140, 914, 2017.

19. MOAZENI M., NIKAEEN M., HADI M., MOGHIM S., MOUHEBAT L., HATAMZADEH M., HASSANZADEH A. Estimation of health risks caused by exposure to enteroviruses from agricultural application of wastewater effluents. Water Research. 125, 104, 2017.

20. LÜ J., JIAO W., QIU H., CHEN B., HUANG X., KANG B. Origin and spatial distribution of heavy metals and carcinogenic risk assessment in mining areas at You'xi County southeast China. Geoderma. 310, 99, 2018.

21. BHATTI S.S., SAMBYAL V., NAGPAL A.K. Heavy metals bioaccumulation in Berseem (Trifolium alexandrinum) cultivated in areas under intensive agriculture, Punjab, India. Springerplus. 2016.

22. SAHITO A., KAZI T.G., JAKHRANI M.A., KAZI G.H., SHAR G.Q., MEMON M.A. Elemental investigation of Momordica charantia Linn., and Syziginm jambolana Linn., using atomic absorption spectrophotometer. The Nucleus. 39, 49, 2002.

23. YANG Y., NAN Z., ZHAO Z. Bioaccumulation and translocation of cadmium in wheat (Triticum aestivum L.) and maize (Zea mays L.) from the polluted oasis soil of Northwestern China. Chemical Speciation \& Bioavailability. 26 (1), 43, 2014.

24. ABEGUNRIN T.P., AWE G.O., IDOWU D.O., ADEJUMOBI M.A. Impact of wastewater irrigation on soil physico-chemical properties, growth and water use pattern of two indigenous vegetables in southwest Nigeria. Catena. 139, 167, 2016.

25. CAMPBELL P.G.C. Cadmium-A priority pollutant. Environmental Chemistry. 3 (6), 387, 2006.

26. AHMAD K., EJAZI A., AZAM M., KHAN Z. I. ASHRAF M., AL-QURAIN F., FARDOUS A., GONDAL S., BAYAT A.R., VALEEM E.E. Lead, cadmium and chromium contents of canola irrigated with sewage water. Pak. J. Bot. 43 (2), 1403, 2011.

27. SHAKIR E., ZAHRAW Z., HAMEED A., AL-OBAIDY M.J. Environmental and health risks associated with reuse of wastewater for irrigation. Egypt. J. Petrol. 2016.

28. ZANGO M.S., ANIM-GYAMPO M., AMPADU B. Health Risks of Heavy Metals in selected Food Crops cultivated in Small-scale Gold-mining Areas in Wassa-Amenfi-West District of Ghana. Journal of Natural Sciences Research. 3 (5), 2224, 2013.

29. BHATTI S.S., KUMAR V., SAMBYAL V., SINGH J., NAGPAL A.K. Comparative analysis of tissue compartmentalized heavy metal uptake by common forage crop: A field experiment. Catena. 160, 185, 2018.

30. WHO/FAO. Joint FAO/WHO Food Standard Programme Codex Alimentarius Commission $13^{\text {th }}$ Session. Report of the Thirty eight Session of the Codex Committee on Food Hygiene, Houston, United States of America (ALINORM 07/30/13), 2007. 